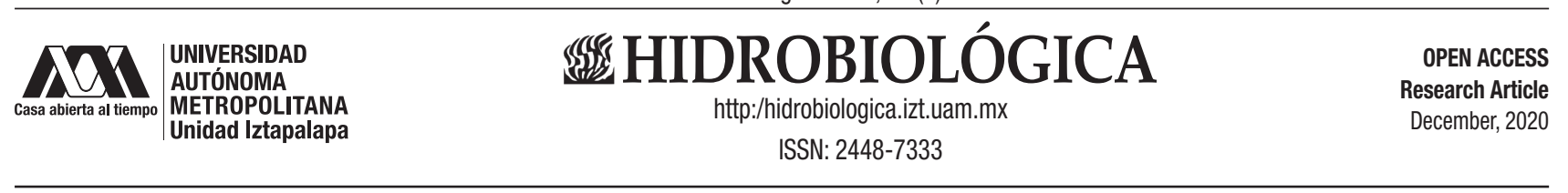

\title{
Productive performance of the Guayas cichlid (Mesoheros festae) fed palm meal based diets during the juvenile stage
}

\author{
Rendimiento productivo de la vieja colorada (Mesoheros festae) alimentada con dietas basadas en torta de palmiste durante \\ la etapa juvenil
}

\author{
Edison Mazón Paredes ${ }^{1, \star \oplus}$, Marcelino Herrera Rodríguez2,5, Marlene Mazón Paredes ${ }^{3}$, Antón García Martínez ${ }^{4}$ Carlos Mazón Paredes ${ }^{1}$ \\ and José Luis Guzmán Guerrero ${ }^{5}$
}

\begin{abstract}
' School of Zootechnical Engineering, Faculty of Livestock Sciences, Quevedo State Technical University. Avenida Quito Km 1 1⁄2 via a Santo Domingo, Quevedo, Los Ríos, 120501. Ecuador.

2 IFAPA Centro Agua del Pino. El Rompido-Punta Umbría rd., Cartaya, Huelva, 21450. Spain.

${ }^{3}$ Ecotourism Engineering School, Faculty of Life Sciences, Amazon State University. CaIle Teniente Hugo Ortíz E45, Puyo, Pastaza 160150. Ecuador.

${ }^{4}$ Faculty of Veterinary Medicine, University of Cordoba. Plaza de Puerta Nueva, s/n Cordoba, 14002. Spain.

${ }^{5}$ Departamento de Ciencias Agroforestales Escuela Técnica Superior de Ingeniería, Universidad de Huelva, Campus de Excelencia Internacional Agroalimentario, "ceiA3", Campus de la Rábida. Palos de la Frontera, Huelva, 21819. Spain.
\end{abstract}

${ }^{*}$ Corresponding author:

Edison Mazón Paredes: e-mail: emazon@ uteq.edu.ec

To quote as:

Mazón-Paredes, E., M. Herrera-Rodríguez, M. Mazón-Paredes, A. García-Martínez, C. Mazón-Paredes \& J. L. Guzmán-Guerrero. 2020. Productive performance of the Guayas cichlid (Mesoheros festae) fed palm meal based diets during the juvenile stage. Hidrobiológica 30 (3): 251-258.

DOl:10.24275/uam/izt/dcbs/hidro/2020v30n3/ Mazon

\section{ABSTRACT}

Background: The increasingly aquaculture development has favored the searching of new protein sources for fish feeding. Goals: 1) trying to present the first data on the culture of an important commercial species in Ecuador, 2) replacing the protein source for feeding in order to minimize the global problem of the fish-based meals in aquaculture. Methods: Guayas cichlid juvenile fish were submitted to four feeding treatments: $0 \%$, $4 \%, 8 \%$ and $12 \%$ palm cake inclusion for 30 days. Several zootechnnical indexes were calculated and analyzed at the end of the experimental culture, as well as the feed proximal composition. Results: The inclusion up to $8 \%$ palm cake did not affect the apparent digestibility of dry matter, crude protein or gross energy. No differences were found in final weight, growth rate, food conversion rate, protein efficiency rate, and protein productive value among 0, 4 and $8 \%$ palm meal content treatments. As the percentage of palm kernel meal in the diets was increased, the food conversion rate decreased, increasing palm meal in diets decreased costs. Conclusions: The productive performance was not affected by the palm cake replacement in diets up to $8 \%$ with palm meal and deriving in lower feed production costs.

Key Words: Apparent digestibility, experimental diets, juvenile stage, palm meal

\section{RESUMEN}

Antecedentes: La expansión de la acuicultura ha favorecido el estudio de fuentes de proteínas para la alimentación de peces. Objetivos: 1) tratar de presentar los primeros datos sobre el cultivo de una importante especie comercial en Ecuador, 2) reemplazar la fuente de proteína para la alimentación con el fin de minimizar el problema global de las comidas a base de harina de pescado en la acuicultura. Métodos: Juveniles de vieja colorada fueron sometidos a cuatro tratamientos de alimentación: 0\%, 4\%, 8\% y $12 \%$ de inclusión por torta de palmiste durante 30 días. Se calcularon y analizaron varios índices zootécnicos al final del cultivo experimental, así como la composición proximal de las dietas experimentales. Resultados: La inclusión del 8\% de torta de palmiste no afectó a los coeficientes de digestibilidad de materia seca, proteína cruda o energía bruta. No se encontraron diferencias en peso final, tasa de crecimiento, tasa de eficiencia de la proteína y valor productivo de la proteína entre los tratamientos de 0,4 y $8 \%$ de contenido en torta de palmiste. Conforme creció el porcentaje de torta de palmiste en la dieta aumentó la tasa de conversión del alimento. El aumento de la torta de palmiste en las dietas redujo los costes. Conclusiones: El rendimiento productivo no se vio afectado por la sustitución de dietas incluyendo hasta un 8\% por torta de palmiste, y derivando en menores costes de producción.

Palabras Clave: Dietas experimentales, digestibilidad aparente, fase juvenil, torta de palmiste 


\section{INTRODUCTION}

The accelerated growth of aquaculture provides half of all the fish for human consumption that is sold in the world, and more than half of the value of fish exports comes from developing countries. However, this has required high quality and high-cost ingredients for fish feed making, which has limited the development of low-cost diets and hindered the sustainability of the industry (Bureau, 1996). In fish farming, feed exceeds $70 \%$ of production costs; it is the most sensitive item, and both technicians and producers should give it greater attention, given the constant changes in the aquaculture and technology market, which offers new alternatives in ingredients and additives that can be used advantageously in the different phases of the production process (Abimorad \& Carneiro, 2004; Cavalheiro et al., 2007). Fishmeal from wild fish remains the main source of protein for commercial aquaculture (Bureau, 1996), and fish meal from wild fish is still the main source of protein for farmed fish (El-Sayed, 1999). For this reason, the growth and sustainable production of aquaculture has sought to progressively reduce the use of fish meal (Francis et al., 2001), and is the main challenge for the industry (Pelletier \& Tyedmers, 2007).

Currently in Ecuador there is not a constant and adequate supply of high protein and high energy plant resources for preparing fish farming diets, highlighting the need to explore new alternative plant resources to replace high-cost conventional sources and evaluate their nutritional potential, such as palm meal (Meurer et al., 2003; Lund et al., 2011; Tusche et al., 2011), which is obtained through the processing of oil palm (Elaeis guineensis). The inclusion of palm meal as an alternative source of protein to replace fishmeal in aquaculture has received little investigation in tropical countries such as Ecuador. Some initial studies have reported that palm meal can be up to $30 \%$ of rations for catfish (Clarias gariepinus) and $20 \%$ for tilapia (Oreochromis niloticus) (Saad et al., 1994).

According to Köprücü \& Özdemir (2005), it is known that feed seems to be an excellent source of nutrients based on its chemical composition, but it is also necessary that the food is tested in vivo, assessing the digestion and other nutritional processes in target species. In this sense, digestibility is one of the parameters used to measure the nutritional value of different food inputs (Anderson et al., 1995; Pezzato et al., 2002; Gonçalves et al., 2003). It is defined as "the bioavailability of nutrients in feed and indicates the amount of an ingredient in the feed that is digested and absorbed by the body and not excreted in the feces" (De Souza et al., 2012). These authors pointed that it is not enough to have high levels of protein and energy in the food though they must also be digestible in order to be assimilated and thus utilized by the organism that consumes them.

Rodriguez et al. (2017) have reported on the breeding of the Guayas cichlid (Mesoheros festae) in Ecuador, an autochthonous species which is of great interest due to its popularity and commercial value, exceeding that of tilapia and other native tropical freshwater species. It is a popular species in rural areas and is also marketed world-wide as an ornamental fish. However, few research studies exist on this species thus farming technologies need to be developed according to the characteristics and needs of this species along its different developmental stages and regions. It is also necessary to study and conserve this ichthyological resource that is characteristic of Ecuadorian lowland inland waters, which is increasingly threatened by overfishing, river pollution and replacement by foreign commercial species. However, it is a carnivorous species (Stawikowski \& Werner, 1998), hence its potential culture would be limited for that reason. In any case, to our knowledge no work has been published on its nutritional requirements, therefore this issue joint to the search of alternative protein sources for fish feeding in Ecuador is a high interest subject.

This study was carried out to extend the knowledge of palm cake as an animal feed ingredient and study the effect of palm cake-based diets on the performance of the Guayas cichlid (Mesoheros festae) in the juvenile stage in the dry season.

\section{MATERIAL AND METHODS}

Location. This study was carried out at "El Peñón del Río" farm near Pambilar de Calope (Los Ríos, Ecuador), in canton Quinsaloma. The geographic coordinates are $1^{\circ} 12^{\prime} 19^{\prime \prime} \mathrm{S}, 79^{\circ} 29^{\prime} 36^{\prime \prime} \mathrm{W}$, and the elevation is 75 meters above sea level. It is located in the tropical rainforest ecological zone, with an average annual ambient temperature of $25.47^{\circ} \mathrm{C}$, average relative humidity of $85.84 \%$ and average annual rainfall of $2,223.85 \mathrm{~mm}$. The study was carried out in July and August 2016 (dry season) over a 30-day period (Fig. 1).

Experimental design. Four isoproteic and isocaloric experimental diets, T0, T4, T8 and T12, were formulated with approximate percentages of palm kernel meal of $0,4,8$ and $12 \%$, respectively, based on the inputs and the amounts indicated in Table 1. The proximal composition of palm kernel cake (dry matter basis) is as follows: $98.42 \%$ of dry matter content, $18.37 \%$ of crude protein content, $9.87 \%$ of ether extract content, $23.29 \%$ of crude fiber content and the crude and metabolizable energy values found were $4.81 \mathrm{Mcal} / \mathrm{kg} \mathrm{DM}$ and $1.81 \mathrm{Mcal} / \mathrm{kg} \mathrm{DM}$, respectively (Mazón et al., 2020). And the amino acid composition is: Iysine (2.68\%), methionine $(1.76 \%)$, threonine $(2.75 \%)$, tryptophan (1.1\%). Essential amino acids (lysine, methionine, arginine, cysteine and tryptophan) were determined by Ultra-High Performance Liquid Chromatography (UHPLC) (Table 1). For preparing the diets, the manual of nutritional needs of Nile Tilapia by Torres-Novoa \& Hurtado et al. (2012), University of The Llanos, Colombia, was used. Experimental diets were extruded using a low-density system which resulted in a granulated appearance. Experimental foods were analyzed for proximal composition, according to the Association of Analytical Communities methodologies (AOAC, 2015). Briefly, the gross energy was determined through a Parr Instruments $121 \mathrm{AE}$ adiabatic calorimetric pump, and gross protein by means of the Kjeldahl method (\% N x 6.25). Lipid content was measured by solvent extraction with a soxhlet apparatus, and ash by incineration at $550^{\circ} \mathrm{C}$ by $6 \mathrm{~h}$. Crude fiber was determined after acid digestion and burning. The $\mathrm{Ca}$ and $\mathrm{P}$ contents were analyzed through the permanganate and molybdate reactions, respectively. Dry matter (DM) was calculated by kiln drying at $105^{\circ} \mathrm{C}$ by $24 \mathrm{~h}$. A completely randomized design was used, with four treatments (4 diets having a different percentage of palm kernel meal), four replicates (4 cages) per treatment and 25 fish per cage. Data collection was performed for 30 days.

Fish management. Four hundred Mesoheros festae juveniles with an initial weight of $10.8 \pm 0.5 \mathrm{~g}$ were used (mean $\pm \mathrm{SE}$ ), at 25 fish per cage $\left(0.270 \mathrm{~kg} \mathrm{~m}^{-3}\right)$. There were 16 experimental cages of $1 \times 1 \times 1 \mathrm{~m}$, covered with $6 \times 8 \mathrm{~cm}$ extruded plastic mesh, and immersed in a $30 \mathrm{x}$ $20 \times 0.8 \mathrm{~m}$ container tank. An electric scale of $5 \mathrm{~kg}$ maximum weight $( \pm$ $1 \mathrm{~g}$ precision) was used to record biometric data, and the experimental diets were supplied through spring tube feeders $(30 \times 150 \mathrm{~cm})$. The 


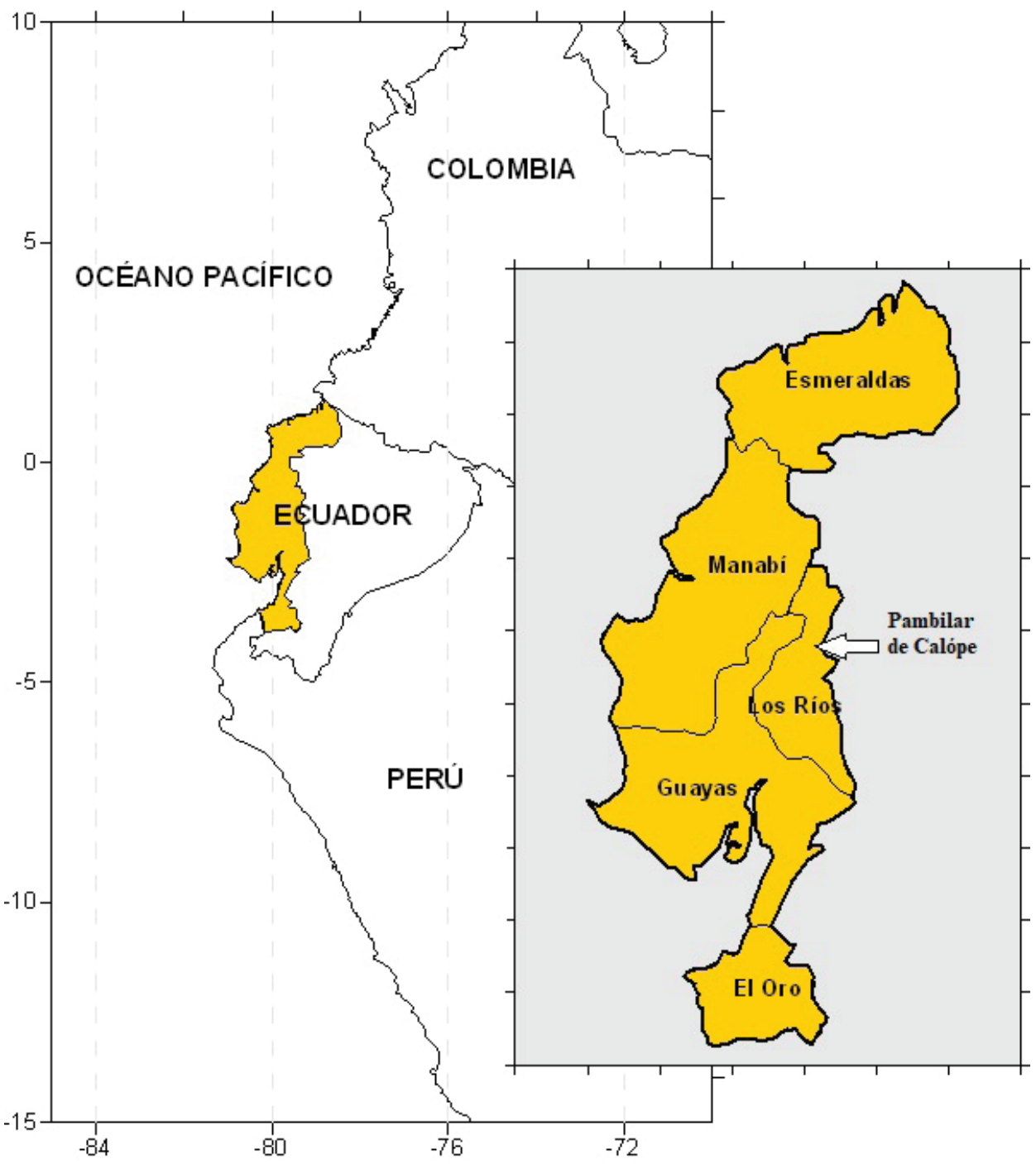

Figure 1. Location of the experimental area in the canton Quinsaloma.

pond did not have aeration equipment because it was supplied by a constant $15 \mathrm{~L} \mathrm{~min}^{-1}$ flow of highly oxygenated, double filtered water from a 0.25 ha reservoir.

The water temperature was $19.5 \pm 0.5^{\circ} \mathrm{C}$. The dissolved oxygen content of the water in the container tank was maintained at $10 \pm 1$ $\mathrm{mg} \mathrm{L}^{-1}$ and the $\mathrm{pH}$ was $6.7 \pm 0.5$. Nitrogenated wastes (unconsumed food and excreted organic matter) were removed daily using a Monge drainage system. The fish had seven days to adapt to the experimental cages before the start of the experiment and were fed extruded food with a high protein content to accustom them to concentrated feed. The experimental diets were offered ad libitum four times a day (08:15, $11: 15,13: 15$ and 15:15 hours) for 30 days. As prophylactic measure, the fish were also treated with a solution of methylene blue $\left(0.8 \mathrm{~g} \mathrm{~L}^{-1}\right)$ after each sampling for preventing Ichthyopthirius fungus and pathogenic bacteria. After each sampling, a solution of methylene blue diluted in water was used to prevent contamination by fungi and bacteria.
Determination of biological parameters. After the experimental period (30 days feeding experimental diets), fish were transferred to metabolic aquariums for the collection of feces, where they remained for a one day fasting period. The direct method of total feces collection based on the modified Guelph system (Satoh et al., 1992) was used for a period of 24 hours, with frequent collections every four hours to avoid degradation and loss of nutrients due to leaching in the water. Feces were dried and stored at $4^{\circ} \mathrm{C}$ until analysis. The metabolic aquariums were cleaned after each feces collection to avoid contamination in each of the treatments. This method used a cylindrical tank with a conical bottom (metabolic aquarium of $200 \mathrm{~L}$ ), with a continuous supply of water and oxygen at the top and a feces collection tube at the bottom (Henry-Silva et al., 2006). Subsequently, a bromatological analysis was carried out on the feces collected and on samples of the experimental diets used in the investigation. The feces were analyzed to determine their proximal composition according to methodologies indicated above (feed analysis). 
Table 1. Ingredients and proximal composition of experimental diets with palm meal used for the juvenile phase of Mesoheros festae.

\begin{tabular}{|c|c|c|c|c|c|}
\hline \multirow{2}{*}{ Ingredients (\%) } & \multicolumn{4}{|c|}{ Experimental diets (\%) } & \\
\hline & $\mathbf{0}$ & 4 & 8 & 12 & \\
\hline Corn & 2.40 & 2.00 & 1.90 & 0.00 & \\
\hline Wheat bran & 4.00 & 2.00 & 0.00 & 0.00 & \\
\hline Rice flour & 5.90 & 4.00 & 1.90 & 0.00 & \\
\hline Soybean cake & 43.00 & 44.00 & 44.00 & 44.30 & \\
\hline Fishmeal & 44.00 & 42.00 & 40.00 & 38.00 & \\
\hline Soybean oil & 0.00 & 1.30 & 3.50 & 5.00 & \\
\hline Palm cake & 0.00 & 4.00 & 8.00 & 12.00 & \\
\hline Salt & 0.10 & 0.10 & 0.10 & 0.10 & \\
\hline Antifungal ${ }^{2}$ & 0.05 & 0.05 & 0.05 & 0.05 & \\
\hline Methionine & 0.20 & 0.20 & 0.20 & 0.20 & \\
\hline Antioxidant ${ }^{3}$ & 0.05 & 0.05 & 0.05 & 0.05 & \\
\hline Choline chloride & 0.10 & 0.10 & 0.10 & 0.10 & \\
\hline Pre-mix ${ }^{4}$ & 0.10 & 0.10 & 0.10 & 0.10 & \\
\hline Enzyme $^{5}$ & 0.10 & 0.10 & 0.10 & 0.10 & \\
\hline Proximal composition (\%) & & & & & Request $^{6}$ \\
\hline Digestible dietary energy $\left(\mathrm{Kcal} \mathrm{Kg}^{-1}\right)$ & 2.76 & 2.7 & 2.71 & 2.66 & 2.75 \\
\hline Total protein & 40.00 & 40.00 & 40.00 & 40.00 & 40.00 \\
\hline Fiber & 3.80 & 4.30 & 4.70 & 5.40 & --- \\
\hline Calcium & 2.01 & 2.02 & 2.06 & 1.98 & 1.00 \\
\hline Phosphorus $^{7}$ & 1.60 & 1.60 & 1.60 & 1.50 & 0.0 \\
\hline Arginine & 2.27 & 2.26 & 2.31 & 2.35 & 1.79 \\
\hline Lysine & 2.44 & 2.39 & 2.39 & 2.36 & 0.94 \\
\hline Met + Cys & 1.24 & 1.22 & 1.21 & 1.20 & 0.35 \\
\hline Tryptophan & 0.43 & 0.42 & 0.42 & 0.41 & 0.30 \\
\hline
\end{tabular}

${ }^{1}$ Air dried food; ${ }^{2}$ Mollejosanitin; ${ }^{3}$ Endox; ${ }^{4}$ Rovimix Pre-mix: Vitamin A, D3, K, E, B1, B2, B6, Nicotinic Acid, Calcium Pantothenate, Biotin, Folic Acid, Choline, Inositol and Vitamin C; ${ }^{5}$ Avizyme 1502 (600 U g-1 endo-1,4 beta xylanase EC 3,2,1,8; $8000 \mathrm{U} \mathrm{g}^{-1}$ subtilisin - protease- EC 3,4,21,62; $800 \mathrm{U} \mathrm{g}^{-1}$ alpha amylase EC 3,2,1,1.); ${ }^{6}$ Torres-Novoa [18]; ${ }^{7}$ Total phosphorus in the diet.

The performance of the Guayas cichlids was evaluated by measuring and using the following zootechnical parameters (Aguirre, 2015; Teixeira et al., 2010):

Food conversion rate $(\mathrm{FC})$ :

$$
\mathrm{FC}=\text { Amount of food provided }(\mathrm{g}) / \text { Weight gain of the fish }(\mathrm{g})
$$

Weight increase (WI):

$$
\mathrm{WI}=(\text { final weight }- \text { initial weight })
$$

Relative weight increase (RWI):

RWI $(\%)=100 \times$ (final weight - initial weight) / (initial weight)
Growth rate $(\mathrm{GR})$ :

$$
\mathrm{GR}(\%)=100 \times(\text { final weight }- \text { initial weight)/time period }
$$

Specific growth rate (SGR):

SGR $(\% /$ day $)=100 \times(\operatorname{Ln}($ final weight $)-\operatorname{Ln}($ initial weight) $) /$ time period

The net feed consumption (NFC):

$$
\text { NFC = Weight of food consumed }(\mathrm{g}) \text { - Weight of waste }(\mathrm{g})
$$

Digestibility coefficient:

Digestibility $(\%)=100 \times$ (nutrient intake - nutrient in feces)/nutrient intake 
Protein efficiency rate (PER):

$$
\mathrm{PER}=\mathrm{WI} / \text { Protein intake }
$$

Productive value of the protein (PPV):

$$
\mathrm{PPV}=\text { Protein retained } / \text { protein intake }
$$

The mortality rate (MR) of Mesoheros festae was recorded over 30 days in each experimental unit according to the following formula: MR $(\%)=100 \times($ dead fish/initial fish).

The cost of each feeding treatment $\left(\$ \mathrm{Kg}^{-1}\right)$ was calculated taking into account the unit value per kilogram of the inputs, products and byproducts that were used in each of the experimental diets, multiplied by the amount of the ingredient used. The cost per fish weight gain (\$ $\mathrm{Kg}^{-1}$ ) was also calculated ( $\mathrm{FC} \times$ feeding cost). The fixed costs and the variable costs of the treatments were not taken into account.

Statistical analysis. Firstly, the normality and homoscedasticity of the data groups were checked through the Kolmogorov-Smirnov and Levene tests, respectively. All the zootechnnical parameters were analyzed through an ANOVA test using the General Linear Model (GLM) of the Statistical Analysis System Software statistical package (Workflow Studio 1.3) System for Windows 11, Copyright 2016 by SAS Institute Inc., Cary, NC, USA. The model considered the percentage of palm kernel meal as factor with four levels $(0 \%, 4 \%, 8 \%$ and $12 \%)$. As post-hoc test, the Tukey test was used to detect significantly homogeneous groups $(p=0.05)$. Values are expressed as mean \pm standard error of the mean (SE).

\section{RESULTS}

Digestibility of experimental diets. The apparent digestibility of dry matter, digestibility of crude protein and digestibility of gross energy are shown in Table 2. When comparing the control diet $(0 \%)$ with diets containing $4 \%$ and $8 \%$ palm kernel meal, no significant differences were found in the apparent digestibility coefficients, though significant differences were found between 0,4 and $8 \%$ treatments and the treatment containing $12 \%$ palm kernel meal. Moreover, it can be seen that this last treatment had the lowest digestibility coefficient compared with the other treatments. No significant differences were found in the apparent digestibility coefficients between the control diet $(0 \%)$ and diets containing $4 \%$ and $8 \%$ palm kernel meal, however the lowest value was obtained with the diet containing the highest percentage (12\%).

Productive performance. The productive performance of Guayas cichlid fed different isoproteic and isocaloric diets of palm kernel meal is shown in Table 3.

No significant differences were found FW, GR, SGR, PER, and PPV between the control diets (0\%) and the diets with 4 and $8 \%$ palm kernel meal, although the lowest value was obtained for the diet containing the highest percentage (12\%). Similarly, no significant differences were found for FC values among the control diets $(0 \%)$ and the diets with 4 and $8 \%$ palm kernel meal. However, the lowest value of FC was obtained for the diet containing the highest percentage (12\%).

No significant differences were found the end of the experimental period in the RWI of Mesoheros festae for diets with 4 and $8 \%$ palm kernel meal. The control diet (0\%) showed the best results and the diet with the highest percentage (12\%) showed the poorest results. Regarding feeding costs, the cost per kilogram of the diet prepared with the highest soybean cake content $(0 \%$ palm kernel meal) was the highest. As the soybean cake in the diet was replaced by palm kernel meal ( $4 \%, 8 \%$, and $12 \%$ palm kernel meal), the cost was reduced. However, the values for feed cost per fish weight gain were 1.3, 1.29, 1.26, and $1.5 \mathrm{USD} \mathrm{Kg}^{-1}$ for $0,4,8$, and $12 \%$ diets, respectively. The mortality for the different treatments was less than $5 \%$ (Table 3).

\section{DISCUSSION}

In general, the results of our research agree with the data of Amaya et al. (2003), who used fish diets in the development stage of red tilapia that included up to $8 \%$ palm kernel meal, without affecting the fish yield, suggesting that higher levels could be used. Also, Vásquez et al. (2013) with hybrid tilapia (Oreochromis sp.) and Vásquez et al. (2013), with cachama (Piaractus brachypomus) did not find negative effects in the productive parameters using up to $8 \%$ palm kernel meal, as well as Bermudez et al. (2012) using $7 \%$ in Nile tilapia (Oreochromis niloticus). However, the worst results in the performance parameters of Mesoheros festae involved the diet of $12 \%$ palm kernel meal.

Table 2. Apparent digestibility coefficients, dry matter (DMD), crude protein (GPD) and gross energy (GED), in Mesoheros festae juveniles fed diets with palm meal.

\begin{tabular}{lcccc}
\hline \multirow{2}{*}{ Variable (\%) } & \multicolumn{4}{c}{ Experimental diets (\%) } \\
\cline { 2 - 5 } & $\mathbf{0}$ & $\mathbf{4}$ & $\mathbf{8}$ & $\mathbf{1 2}$ \\
\hline DMD & $57.7 \pm 1.26 \mathrm{a}$ & $57.8 \pm 1.26 \mathrm{a}$ & $57.7 \pm 1.26 \mathrm{a}$ & $55.2 \pm 1.26 \mathrm{~b}$ \\
GPD & $82.8 \pm 1.74 \mathrm{a}$ & $82.7 \pm 1.74 \mathrm{a}$ & $82.8 \pm 1,74 \mathrm{a}$ & $78.3 \pm 1.74 \mathrm{~b}$ \\
GED & $74.9 \pm 1.18 \mathrm{a}$ & $74.9 \pm 1.18 \mathrm{a}$ & $74.9 \pm 1.18 \mathrm{a}$ & $72.5 \pm 1.18 \mathrm{~b}$ \\
\hline
\end{tabular}

${ }^{a b c}$ Averages on the same line that have different letters differ statistically according to the Tukey test $(p \leq 0.05)$.

${ }^{\dagger}$ Mean $( \pm$ SE) of 4 replicates per treatment. 
Table 3. Effect of diets having different percentages of palm meal on the productive performance indices of Mesoheros festae juveniles.

\begin{tabular}{lrrrr}
\hline \multirow{2}{*}{ Variable $^{\ddagger}$} & \multicolumn{4}{c}{ Experimental diets (\%) } \\
\cline { 2 - 5 } & 0 & \multicolumn{1}{c}{8} & 12 \\
\hline Final weight $(\mathrm{g})$ & $14.86 \pm 3.82 \mathrm{a}$ & $14.88 \pm 3.82 \mathrm{a}$ & $14.90 \pm 3.82 \mathrm{a}$ & $12.50 \pm 3.82 \mathrm{~b}$ \\
Weight increase (g) & $4.86 \pm 3.82 \mathrm{a}$ & $4.88 \pm 3.82 \mathrm{a}$ & $4.90 \pm 3.82 \mathrm{a}$ & $2.50 \pm 3.82 \mathrm{~b}$ \\
Relative weight increase (\%) & $52.50 \pm 48.3 \mathrm{a}$ & $49.90 \pm 48.3 \mathrm{~b}$ & $50.30 \pm 48.3 \mathrm{~b}$ & $24.90 \pm 48.3 \mathrm{c}$ \\
Growth rate (\%) & $16.22 \pm 12.8 \mathrm{a}$ & $16.29 \pm 12.8 \mathrm{a}$ & $16.36 \pm 12.8 \mathrm{a}$ & $8.35 \pm 12.8 \mathrm{~b}$ \\
Specific growth rate (\%) & $1.31 \pm 0.83 \mathrm{a}$ & $1.32 \pm 0.83 \mathrm{a}$ & $1.33 \pm 0.83 \mathrm{a}$ & $0.74 \pm 0.83 \mathrm{~b}$ \\
Food consumption (g) & $19.60 \pm 0.01 \mathrm{a}$ & $19.60 \pm 0.01 \mathrm{a}$ & $19.50 \pm 0.01 \mathrm{~b}$ & $19.40 \pm 0.01 \mathrm{c}$ \\
Feed conversion rate & $1.31 \pm 0.42 \mathrm{~b}$ & $1.32 \pm 0.42 \mathrm{~b}$ & $1.31 \pm 0.42 \mathrm{~b}$ & $1.55 \pm 0.42 \mathrm{a}$ \\
Protein Efficiency Rate & $0.125 \pm 0.11 \mathrm{a}$ & $0.126 \pm 0.11 \mathrm{a}$ & $0.127 \pm 0.11 \mathrm{a}$ & $0.065 \pm 0.11 \mathrm{~b}$ \\
Productive Value of Protein & $0.584 \pm 0.15 \mathrm{a}$ & $0.585 \pm 0.15 \mathrm{a}$ & $0.581 \pm 0.15 \mathrm{a}$ & $0.490 \pm 0.15 \mathrm{~b}$ \\
Food cost $\left(\$ \mathrm{Kg}^{-1}\right.$ ) & $0.994 \pm 0.00 \mathrm{a}$ & $0.981 \pm 0.01 \mathrm{~b}$ & $0.963 \pm 0.00 \mathrm{c}$ & $0.969 \pm 0.00 \mathrm{c}$ \\
Fish weight cost $\left(\$ \mathrm{Kg}^{-1}\right)$ & $1.3 \pm 0.41 \mathrm{a}$ & $1.29 \pm 0.41 \mathrm{a}$ & $1.26 \pm 0.41 \mathrm{a}$ & $1.5 \pm 0.41 \mathrm{~b}$ \\
Mortality $(\%)$ & 4 & 3 & 2 & 3 \\
\hline
\end{tabular}

${ }^{a b c}$ Averages on the same line that have different letters differ statistically according to the Tukey test $(p \leq 0.05)$.

${ }^{\ddagger}$ They correspond to the average $( \pm \mathrm{SE})$ of 25 fish housed in a cage (Experimental Unit) with four replications per trial.

The apparent digestibility coefficients achieved in our investigation agree in general with those described for other freshwater fish species. Concretely, similar digestibility of dry matter, digestibility of gross protein and digestibility of gross energy values have been reported by Vásquez et al. (2013) using a diet of $8 \%$ palm kernel meal in hybrid red tilapia (Oreochromis sp.) and cachama (Piaractus brachypomus), and Bermudez et al. (2012) using a diet of $7 \%$ in Nile tilapia (Oreochromis niloticus).

The results obtained for protein efficiency coefficients and productive value of protein in this study are relatively low compared to results obtained by Bermudez et al. (2012) in red tilapia (Oreochromis sp.), Yudy et al. (2004) in yamú (Brycon siebenthalae), De Souza et al. (2012) in Gulf Corvina (Cynoscion othonopterus) and Aguirre (2015) in sabaleta (Briycon henni). These differences may be due to the fact that Mesoheros festae has different feeding habits from those of other commercial species used in previous works. With the increase in the partial substitution of fishmeal by palm meal, there was no decrease in protein efficiency rates in the productive value of protein and the protein efficiency rate up to $8 \%$, this was possibly due to a low-quality protein mixture of that feed formulation, so a low bioavailability of the protein derived in a poor degradation (Martínez \& Muñoz, 2006), regardless the amount of protein available in the food (Abdel-Tawwab et al., 2010). Similar effects were reported by Yudy et al. (2004), by a mixture of low-quality protein with a good quality in the formulation of the food supplied.

In addition, when fishmeal was replaced by palm kernel meal, lower significant growth was observed in fish feed $12 \%$ palm kernel meal. In this sense, Saad et al. (1994), reported that palm meal can be up to $30 \%$ of the diet for feeding catfish (Clarias gariepinus) and $20 \%$ for tilapia without negative effects on development or yield, much higher levels than in our work. With similar results for those species,
Wan \& Alimon (2005) and Wing (2005) found satisfactory results up to a level of $20 \%$. The yield did not change when cachama (Piaractus brachypomus) were fed this alternative source of protein with $7 \%$ palm kernel cake (Vásquez et al., 2013).

As many ingredients based on vegetable protein and oilseed lipids, there are several factors that can limit the inclusion of palm kernel meal in fish diets. These include its relatively low protein content, possible amino acid deficiency (see composition in Material and Methods section) and antinutritional factors (Abdel-Tawwab et al., 2010). Although, in experimental diets with different levels of palm kernel cake, an export fishmeal containing 59\% raw protein (in dry matter), which may have provided adequate levels of amino acids, was used, despite that is synthetic methionine supplement and a premix of vitamins and minerals.

Several authors have states that the low digestibility of the palm kernel cake is normally attributed to high levels of non-starch polysaccharides (NSP) or cell wall composition (Dusterhoft \& Voragen, 1991; Wing, 2005), so that deficiency of amino acids does not appear to be the cause of the poorest yields obtained with the diet containing the highest percentage (12\%). Wing (2005) indicates that those antinutritional factors reduce the digestibility and uptake of the nutrients in palm kernel meal, either by direct encapsulation of the nutrients or by increasing the viscosity of intestinal contents, thus reducing the rate of hydrolysis and absorption of nutrients in the feed. The high fiber content and the inadequacy of the added enzymatic complex could also explain the poor digestibility of high palm cake content diets.

Furthermore, it is known that the addition of proteolytic, fibrolytic or carbohydrate degrading enzymes to palm kernel cake diets has great potential for releasing unavailable nutrients and energy, hence an enzyme complex was used in the experimental diet (Avizyne 1502). $\mathrm{Ng}$ et al. (2002), in studies carried out with tilapia fed palm kernel meal 
pre-treated with enzymes for commercial feed, consistently showed higher growth and feed utilization efficiency compared to fish fed similar levels of raw palm kernel meal.

Regarding feed consumption, diets with higher fishmeal content were more attractive and better accepted by fish than diets formulated with increasing percentages of palm cake, possibly due to odorous substances brought by fishmeal. Similar data were reported by Shapawi et al. (2007) for humpback grouper (Cromileptes altivelis) and De Souza et al. (2012), for Gulf corvina (Cynoscion athonopterus). However, feed conversion was less efficient when the percentage of palm kernel meal was increased, which is consistent with the results obtained by Amaya et al. (2003), although the feed conversion enhanced in red tilapia fingerlings. Also, Vásquez et al. (2013) found positive effects on feed conversion using palm meal as a plant protein source up to $8 \%$ with red tilapia juveniles.

Therefore, overall, it seems that the partial substitution by palm cake can reach the $8 \%$ with no effects on the most of performance indexes. These are the first results on the on growing of the Guayas cichlid (Mesoheros festae) and provide specific zootechnnical data for its potential culture. From the digestibility tests carried out, it is concluded that the inclusion of up to $8 \%$ palm cake meal in diets for feeding Mesoheros festae during juvenile stage did not affect the digestibility of protein or energy, and related parameters. Therefore, the inclusion of up to $8 \%$ palm kernel meal in the diets of Mesoheros festae during on growing would not affect the yield of this species.

Future research should focus on the study of new formulations in order to explore the elimination of antinutritional factors in this food, and to increase the palm kernel meal content.

\section{ACKNOWLEDGEMENTS}

The contract for this research had economic support by the Graduate Department of the State Technical University of Quevedo, Ecuador. Edison Mazón's doctoral student contract is supported by Fourth Notary of the canton Quevedo Los Rios Ecuador. M. Herrera's contract is supported by INIA-FSE.

\section{REFERENCES}

Abdel-Tawwab, M., M. Ahmad, Y. Khattab \& A. Shalaby. 2010. Effect of dietary protein level, initial body weight, and their interaction on the growth, feed utilization, and physiological alterations of Nile tilapia, Oreochromis niloticus. Aquaculture 298 (3): 267-274.

Abimorad, E. \& D. J. Carneiro. 2004. Métodos de colecta de fezes e determinação dos coeficientes de digestibilidade da fração protéica e da energis dos alimentos para o pacu, Piaractus mesopotamicus. Revista Brasileira de Zootecnia 33 (5): 1101-1109.

AguirRe, M. 2015. Evaluación de dos niveles de proteína en dietas para juveniles de Sabaleta (Brycon henni). Revista Colombiana de Investigaciones Agroindustriales 2 (1): 68-69.

Amaya, E., G. Afanador, L. Quintero \& W. Bonilla. 2003. Valor nutricional de la torta de palmiste en dietas prácticas para alevinos de tilapia roja (Oreochromis spp). I Congreso Nacional de Investigaciones Acuícolas, Bogotá. $10 \mathrm{p}$.
Anderson, J. S., S. P. Lall, D. M. Anderson \& M. A. McNiven. 1995. Availability of amino acids from various fish meals fed to Atlantic salmon (Salmo salar). Aquaculture 138 (1): 291-301.

AOAC International. 2005. Official Methods of Analysis. 18th ed. Association of Official Analytical Chemists. Gaithersburg, Maryland. $58 \mathrm{p}$.

Bermúdez, A., A. P. Muñoz \& G. Wills. 2012. Evaluación de un sistema de alimentación orgánico sobre el desempeño productivo de la tilapia nilótica (Oreochromis niloticus) cultivadas en estanques de tierra. Revista de Medicina Veterinaria y Zootecnia 59 (3): 165-175.

BuREAU, D. P. 1996. Nutritional value of rendered animal protein ingredients for salmonids in the 90'S: The Canadian Feed Industry Association and Eastern Nutrition Conference. Nova Scotia, Canada. $8 \mathrm{p}$.

Cavalheiro, 0. J., 0. E. De Souza \& B. P. Singh. 2007. Utilization of shrimp industry waste in the formulation of tilapia (Oreochromis niloticus Linnaeus) feed. Bioresource Technology 98 (1): 602-606.

De Souza, A. P., L. G. Tavares, J. S. Oliveira \& S. J. Ribeiro. 2012. Digestibility of agro-industrial byproducts in 200 and $300-\mathrm{g}$ Nile tilapia. Revista Brasileira de Zootecnia 41 (2): 462-466.

Dusterhoft, E. M. \& A. G. Voragen. 1991. Non-starch and polysaccharides from sunflower (Helianthus annuus) and palm kernel (Elaeis guineensis) meal - preparation of cell Wall material and extraction of polysaccharide fractions. Journal Science Food Agriculture 55 (1): $41-42$.

El-SAYed, A. M. 1999. Alternative dietary protein sources for farmed tilapia Oreochromis spp. Aquaculture 179 (1): 149-168.

Francis, G., H. MakkAR \& K. BeCKER. 2001. Antinutritional factors present in plant-derived alternate fish feed ingredients and their effects in fish. Aquaculture 199 (3): 197-227.

Gonçalves, G. E. \& D. J. Carneiro. 2003. Coeficientes de Digestibilidade Aparente da Proteína e Energia de Alguns Ingredientes Utilizados em Dietas para o Pintado (Pseudoplatystoma coruscans). Revista Brasileira de Zootecnia 32 (4): 779-786.

Henry-Silva, G., A. Camargo \& M. Pezzato. 2006. Eficiencia de los macrófitos acuáticos para tratar los efluentes de los estanques de tilapia del Nilo. Scientia Agricola 63 (5): 1-10.

Köprücü, K. \& Y. ÖZDEMIR. 2005. Apparent digestibility of selected feed ingredients for Nile tilapia (Oreochromis niloticus). Aquaculture 250 (3): 308-316.

Lund, I., J. Dalsgaard, H. Tolderlund, J. Holm \& A. Jokumsen. 2011. Replacement of fish meal with a matrix of organic plant proteins in organic trout (Oncorhynchus mykiss) feed, and the effects on nutrient utilization and fish performance. Aquaculture 321 (1): 259-266.

Martinez, 0. \& V. Muñoz. 2006. Proteínas y péptidos en nutrición enteral. Nutrución Hospitalaria 21 (2): 1-19.

Mazón-Paredes, E., M. Herrera-Rodriguez, C. Mazón-Paredes, A. García-Martínez, M. Delgado-Pertiñez \& J. L. Guzmán-Guerrero. 2020. Bromatological Composition of Palm Kernel Meal According to its Origin and Production Periods Potential Use of Palm Kernel Meal in Animal Feed. Journal of Oil Palm Research 32 (4): 1-8. 
Meurer, F., C. Hayashi \& W. R. Boscolo. 2003. Digestibilidade aparente de alguns alimentos proteicos pela tilápia do Nilo (Oreochromis niloticus). Revista Brasileira Zootecnia 32 (1): 1801-1809.

NG, W. K., H. A. LIM, S. L. LIM \& C. O. IBraHIM. 2002. Nutritive value of palm meal pretreated with enzyme or fermented with Trichodemia koningii (Oudemans) as a dietary ingredient for red hybrid tilapia (Oreochromis sp.). Aquaculture Research 33 (1): 1199-1207.

Pelletier, N. \& P. Tyedmers. 2007. Feeding farmed salmon: Is organic better. Aquaculture 272 (1): 399- 416.

Pezzato, L. E., E. Carvalho de Miranda, M. M. Barros, P. L. G. Quintero, W. M. Furuya \& A. C. Pezzato. 2002. Digestibilidade Aparente de Ingredientes pela Tilápia do Nilo (Oreochromis niloticus). Revista Brasileira de Zootecnia 31 (1): 1595-1604.

Rodríguez, J., M. González, A. Moya, M. Gallegos, J. C. Gómez, E. Angón \& C. BarBA. 2017. Efecto de la densidad de cría sobre el crecimiento del Cichlasoma festae en condiciones controladas de confinamiento durante su etapa juvenil. Revista de Investigación Talentos 4 (1): 2631-2476.

SaAd, C., C. Cheah \& M. Kamaruddin. 1994. Suitability of using palm kernel cake, (PKC) in catfish practical dict. Science and Technology Congress, Kuala Lumpur. 105 p.

Satoh, S., C. Y. Сho \& T. Watanabe. 1992. Effect of Fecal Retrieval Timing on Digestibility of Nutrients in Rainbow Trout Diet with the Guelph and TUF Feces Collection Systems. Nippon Suisan Gakkaishi 58 (6): 1123-1127.
Shapawi, R., W. K. Ng \& S. Mustafa. 2007. Replacement of fish meal with poultry byproduct meal in diets formulated for the humpback grouper, Cromileptes altivelis. Aquaculture 273 (1): 118-126.

StaWIKoWski, R. \& U. Werner. 1998. Die Buntbarsche Amerikas, Band 1. Verlag Eugen Ulmer, Stuttgart. 540 p.

Teixeira, E., E. Oliveira, A. Castro, P. Carvalho, D. Vieira \& L. P. Ribeiro. 2010. Coeficientes de digestibilidad aparente de alimentos energéticos para juvenis de surubim. Revista Brasileira de Zootecnia 39 (6): 1180-1185.

Torres-NovoA, D. \& V. Hurtado. 2012. Requerimientos nutricionales para Tilapia del Nilo (Oreochromis niloticus). Orinoquia 16 (1): 63-68.

Tusche, K., S. Wuertz, A. Susenbeth \& C. Shulz. 2011. Feeding fish according to organic aquaculture guidelines EC 710/2009: Influence of potato protein concentrates containing various glycoalkaloid levels on health status and growth. Aquaculture 319 (1): 122-131.

Vásquez, W., M. Yosa, G. Hernández \& M. Gutiérrez. 2013. Digestibilidad aparente de ingredientes de origen vegetal y animal en la cachama. Pesquisa Agropecuária Brasileira 48 (8): 920-927.

Wan, M. Z. \& A. R. Alimon. 2005. Uso de la torta de palmiste y subproductos de palma de aceite en concentrados para animales. Revista Palmas 26 (1): 57-64.

Wing, K. 2005. Investigación sobre el uso de la torta de palmiste en alimentos para la acuicultura. Revista Palmas 26 (3): 79-83.

Yudy, M., 0. López, W. Vásquez \& F. Álvaro. 2004. Evaluación de diferentes porciones de energía proteína en dietas para juveniles de yamú, Brycon siebenthalae. Orinoquia 8 (1): 64-76. 